\title{
PENGUATAN LITERASI PERUBAHAN IKLIM DI KALANGAN REMAJA
}

\author{
Agusniar Rizka Luthfia ${ }^{1)}$, Nurhayatu Nufut Alimin ${ }^{2)}$, Febriani Sarwendah Asri Nugraheni ${ }^{3)}$, Eka Nada \\ Shofa Alkhajar 4 ) \\ ${ }^{1}$ Program Studi Ilmu Administrasi Negara, Fakultas Ilmu Sosial dan Politik, Universitas Sebelas Maret, \\ Surakarta, Indonesia \\ ${ }^{2}$ Program Studi Desain Interior, Fakultas Seni Rupa dan Desain, Universitas Sebelas Maret, Surakarta, \\ Indonesia \\ ${ }^{3}$ Program Studi Ilmu Pengetahuan Alam, Fakultas Keguruan dan Ilmu Pendidikan, Universitas Sebelas \\ Maret, Surakarta, Indonesia \\ 4 Program Studi Ilmu Komunikasi, Fakultas Ilmu Sosial dan Politik, Universitas Sebelas Maret, Surakarta, \\ Indonesia \\ email: agusniar@staff.uns.ac.id
}

\begin{abstract}
Abstrak
Perubahan iklim adalah sebuah ancaman nyata bagi kehidupan dan peradaban umat manusia. Dampak perubahan iklim yang disebabkan oleh pemanasan global saat ini sudah semakin terlihat di seluruh dunia. Akan tetapi, ada kesenjangan literasi perubahan iklim di tengah masyarakat kita terutama di kalangan remaja. Mitra kegiatan pengabdian ini bahkan mengakui kurangnya pengetahuan yang mereka miliki berkaitan dengan perubahan iklim. Meskipun pada ukuran tertentu mereka telah memiliki pengetahuan tetapi hal ini jelas bukanlah sebuah kondisi yang ideal. Oleh karena itu, penguatan literasi perubahan iklim di kalangan remaja adalah sebuah agenda penting untuk dilakukan. Hasil yang dicapai dari kegiatan pengabdian ini adalah para remaja sadar dan memahami pentingnya melakukan melakukan berbagai langkah nyata untuk mereduksi dampak perubahan iklim di kehidupan mereka sehari-hari.
\end{abstract}

Kata Kunci: literasi perubahan iklim, remaja, pemanasan global

\section{Abstract}

Climate change is a real threat for human life and civilization. Its impacts caused by global warming are currently visible around the world. Unfortunatelly, there is a climate change literacy gap within our society, particularly among teenagers. The target of community devotion even confessed their lack of knowledge related to climate change. Although at a low level criterion they had little knowledge about it but of course this was clearly not an ideal condition. Accordingly, strengthening teenager's climate change literacy is an important agenda to be done. The result achieved from this community devotion is that the target of community devotion became aware and understand the importance to conduct many real actions to reduce climate change impacts in their daily life.

Keywords: climate change literacy, teenagers, global warming

\section{PENDAHULUAN}

Perubahan iklim adalah sebuah persoalan penting yang menjadi ancaman serius bagi seluruh manusia di bumi. Seperti diketahui, pemanasan global yang semakin hari semakin meningkat telah menyebabkan adanya perubahan iklim yang berdampak buruk bagi segenap aspek kehidupan manusia.
Satu hal yang pasti, persoalan ini bukanlah sebuah persoalan yang bisa selesai dengan sendirinya tanpa ada upaya-upaya untuk melakukan aksi-aksi nyata. Apalagi temperatur global dunia sudah semakin tinggi dan terus mengalami kenaikan dari waktu ke waktu. Berikut ini adalah sebuah proyeksi yang menggambarkan mengenai kenaikan temperatur global tersebut. 
kegiatan PKM ini memiliki makna penting untuk dilaksanakan.

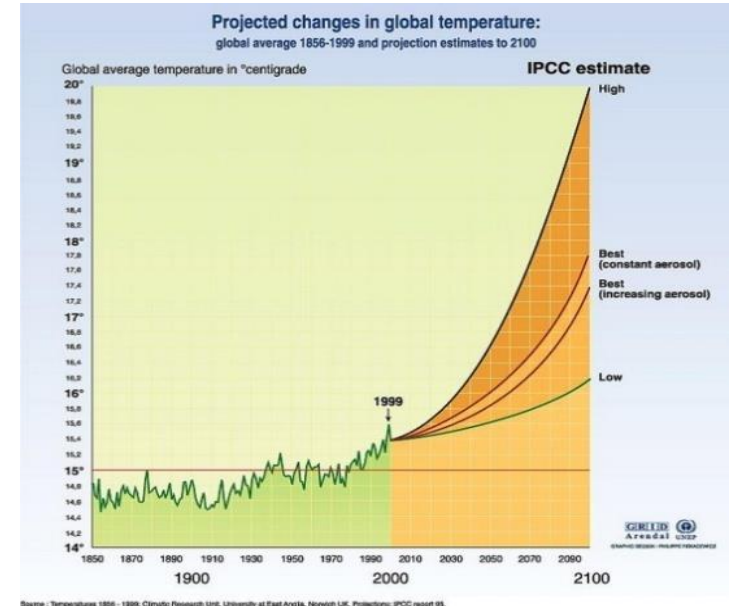

Gambar 1. Proyeksi Perubahan

Temperatur Global (UNEP/GRIDArendal, 2018)

Salah satu langkah yang bisa dilakukan untuk mengurangi dampak perubahan iklim adalah melalui penyebaran kesadaran dan penguatan literasi perubahan iklim. Bahkan edukasi mengenai hal tersebut adalah salah satu agenda yang sangat penting untuk dilakukan (Azeiteiro et al., 2018). Kegiatan pengabdian kepada masyarakat (PKM) ini ditujukan kepada kalangan remaja karena mereka adalah kelompok yang sangat potensial untuk berperan sebagai agen perubahan untuk mengurangi dampak perubahan iklim. Apalagi remaja sebagai bagian dari generasi muda memiliki peran signifikan dan strategis bagi masa depan sebuah bangsa (Alkhajar, 2014).

Dalam fase perkembangan kehidupan manusia, masa remaja adalah sebuah masa transisi atau peralihan dari anak-anak menjadi dewasa. Remaja tidak bisa lagi disebut sebagai anak-anak tetapi mereka juga belum bisa dikatakan dewasa (Shaffer and Kipp, 2010). Meskipun demikian kemampuan afektif, kognitif dan psikomotorik remaja sudah berkembang dengan pesat. Oleh karena itu, remaja diharapkan bisa ikut aktif menyebarkan kesadaran kepada lingkungan sekitarnya serta mampu melakukan berbagai langkah nyata yang diperlukan dalam rangka mereduksi dampak perubahan iklim secara berkesinambungan. Pada konteks itulah
Di sisi lain, kegiatan PKM ini adalah salah satu bentuk pelaksanaan dari Tri Dharma Perguruan Tinggi. Kegiatan PKM adalah salah satu pilar penting yang harus dilakukan sebagai wujud nyata kontribusi perguruan tinggi kepada masyarakat sehingga perguruan tinggi tidak menjadi menara gading dan jauh dari masyarakat.

Sementara itu, langkah yang dilakukan oleh tim PKM ini juga memiliki arti penting sebagai bentuk nyata dari pelaksanaan amanat United Nations Framework Convention on Climate Change (UNFCCC) terutama pada Pasal 6 berkaitan dengan pentingnya peran setiap komponen masyarakat untuk ikut memberikan edukasi dan menyebarkan kesadaran kepada masyarakat mengenai perubahan iklim (UNFCCC, 1992). Apalagi tugas untuk merawat dan menjaga bumi agar selalu menjadi sebuah planet yang ramah bagi kita dan generasi yang akan datang adalah tugas kita bersama (Luthfia and Alkhajar, 2018).

\section{Profil Mitra}

Mitra yang dipilih sebagai sasaran pelaksanaan kegiatan PKM adalah kelompok remaja Masjid Al-Fatah di Dukuh Trowangsan, Desa Malangjiwan, Kecamatan Colomadu, Kabupaten Karanganyar. Pemilihan kelompok remaja tersebut didasarkan karena hampir seluruh remaja di wilayah tersebut tergabung didalamnya. Selain itu, berdasarkan hasil observasi ditemukan bahwa mitra belum pernah mengikuti kegiatan yang berkaitan dengan penguatan dan penyadaran tentang perubahan iklim serta pentingnya literasi perubahan iklim. Mereka yang tergabung dalam kelompok remaja tersebut memiliki rentang usia 12-16 tahun. Oleh karena itu, para remaja ini bisa dikatakan berada pada kategori antara remaja awal dan remaja pertengahan (Barrett, 1996).

\section{METODE PELAKSANAAN}

Dalam rangka mewujudkan tujuan yang diharapkan, tim kegiatan PKM sebelumnya telah melakukan langkah-langkah 
yang diperlukan untuk kelancaran pelaksanaan kegiatan PKM seperti berkomunikasi secara intens dengan mitra dan pembimbing mitra Bapak Budi Santoso, mengurus ijin pelaksanaan kegiatan, mempersiapkan materi serta menyediakan sarana dan fasilitas yang diperlukan pada saat penyelenggaraan kegiatan.

Kegiatan ini dilaksanakan pada 29 Desember 2018. Adapun metode yang digunakan antara lain ceramah, konsultasi, diskusi kelompok dan tanya jawab. Metode tersebut dipilih karena dinilai paling sesuai untuk menyampaikan edukasi tentang pentingnya literasi perubahan iklim kepada kelompok mitra. Adapun total peserta yang mengikuti kegiatan PKM ini berjumlah sebanyak 30 orang.

\section{HASIL DAN PEMBAHASAN}

Dalam kegiatan PKM ini para peserta diberikan berbagai materi mengenai perubahan iklim, pemanasan global, urgensi remaja memiliki literasi perubahan iklim yang baik serta langkah-langkah nyata apa yang bisa dilakukan untuk mengurangi dampak perubahan iklim. Tim PKM menyampaikan berbagai materi tersebut secara bergantian. Dalam kegiatan ini seluruh peserta diberikan sebuah pemahaman yang lebih mendalam mengenai pemanasan global yang menyebabkan terjadi perubahan iklim.

Pemberian materi-materi ini selain bertujuan untuk memperkuat literasi perubahan iklim juga dimaksudkan untuk menumbuhkan rasa tanggung jawab di kalangan remaja tersebut untuk turut aktif berpartisipasi dalam upaya mengurangi dampak perubahan iklim sesuai dengan kemampuan yang mereka miliki.

Dalam kegiatan ini tim PKM juga bertindak sebagai fasilitator dan teman diskusi bagi para remaja. Selain itu, tim PKM juga menerapkan prinsip pembelajaran yang menempatkan para remaja tersebut bukan sebagai obyek pasif tetapi sebagai subyek aktif. Oleh karena itu, dalam setiap sesi materi, para peserta memiliki keleluasaan untuk mengajukan pertanyaan ataupun tanggapan secara langsung ketika dirasa ada materi yang belum mereka pahami dengan baik sehingga terjadi sebuah ruang diskusi interaktif dua arah yang hidup.

Tim PKM juga memperkaya materimateri yang disampaikan dengan menggunakan berbagai ilustrasi dan animasi menarik. Ini dilakukan agar pesan-pesan yang disampaikan dapat lebih mudah ditangkap oleh para peserta. Seorang pakar pernah mengatakan bahwa animasi adalah sebuah bentuk kreatif yang paling penting di abad ke21. Lebih dari itu, animasi tidak hanya peruntukkan untuk hiburan tetapi bisa digunakan sebagai sarana pendidikan (Wells, 2002).

Sebagai contoh tim PKM menggunakan sebuah film animasi berjudul "Global Warming for Kids" yang dipublikasikan oleh Smart Learning for All (2015) di kanal Youtube mereka. Para peserta mengungkapkan bahwa kegiatan ini sangat bermanfaat bagi mereka karena selama ini mereka tidak mengetahui secara jelas apa itu perubahan iklim. Para peserta juga memberi tanggapan yang baik berkaitan dengan penggunaan berbagai ilustrasi dan animasi dalam kegiatan ini.

Menurut mereka hal tersebut adalah langkah yang tepat karena bisa membuat suasana kegiatan PKM menjadi lebih menarik dan dapat membantu mereka untuk memahami pesan-pesan yang disampaikan. Mereka menilai kegiatan PKM ini telah banyak membantu mereka dalam memberi gambaran tentang langkah-langkah apa yang bisa dilakukan untuk mereduksi dampak perubahan iklim. 

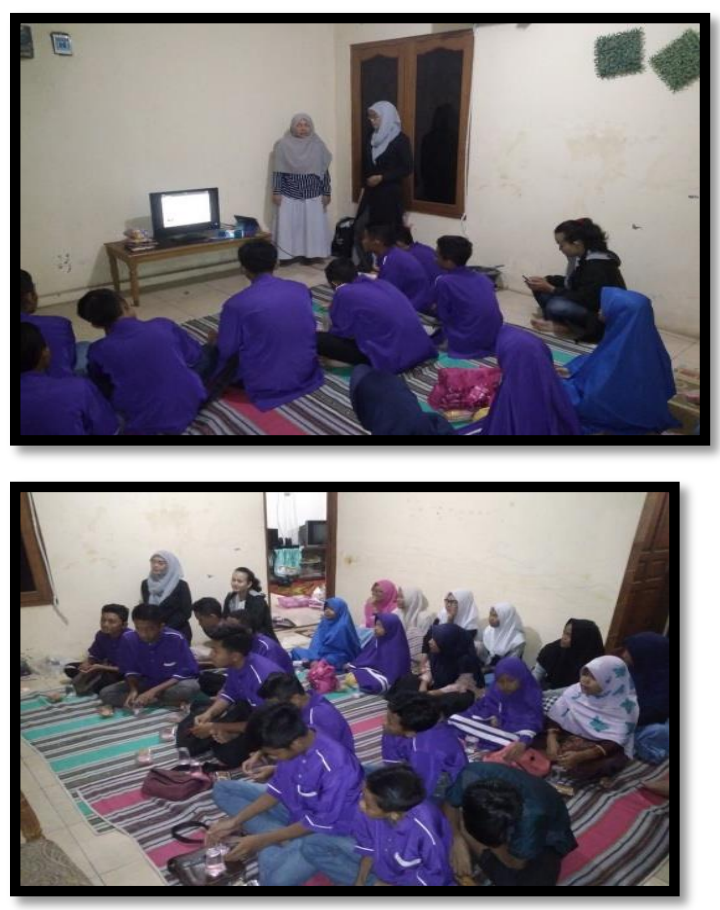

Gambar 2. Dokumentasi Pelaksanaan Kegiatan Pengabdian

\section{KESIMPULAN}

Literasi perubahan iklim sangat diperlukan dan sangat penting untuk dimiliki oleh para remaja. Dengan adanya literasi perubahan iklim para remaja akan lebih termotivasi untuk ikut berpartisipasi dan memainkan peranan penting mereka dalam upaya mengurangi dampak perubahan iklim.

Kegiatan pengabdian ini mendapatkan respon positif dari seluruh peserta. Dari evaluasi yang dilakukan di akhir kegiatan bisa diketahui bahwa pengetahuan dan pemahaman peserta tentang perubahan iklim dan pentingnya literasi perubahan iklim telah meningkat dan menguat dibandingkan sebelum mengikuti kegiatan.

Para peserta berharap agar kegiatan semacam ini bisa dilaksanakan dan dilanjutkan secara berkelanjutan di kemudian hari karena sangat bermanfaat untuk mereka sebagai generasi muda.

\section{REFERENSI}

Alkhajar, Eka Nada Shofa. 2014. Media, Masyarakat dan Realitas Sosial. Surakarta: Sebelas Maret University Press.

Azeiteiro, Ulisses M., Walter Leal Filho and Luisa Aires. (eds.) 2018. Climate Literacy and Innovations in Climate Change Education. Cham: Springer International Publishing AG.

Barrett, David E. 1996. "The Three Stages of Adolescence." The High School Journal, 79(4): 333-339.

Luthfia, Agusniar Rizka and Eka Nada Shofa Alkhajar. 2018. "Strengthening Public Awareness on Climate Change: Lesson learned from a youth social movement in Yogyakarta, Indonesia." IOP Conference Series: Earth and Environmental Science, Vol. 200, 012033. DOI : $10.1088 / 1755-$ 1315/200/1/012033

Shaffer, David R. and Katherine Kipp. 2010. Development Psychology: Childhood and Adolescence. 8th Ed.Belmont, CA: Wadsworth, Cengage Learning.

Smart Learning for All. 2015. "Global Warming for Kids." Youtube, 28 Mei.

UNEP/GRID-Arendal. 2018. "Projected Changes in Global Temperature." United Nations Environment Programme/GRID-Arendal. www.inforse.org.

UNFCCC. 1992. United Nations Framework Convention on Climate Change. United Nation: UNFCCC.

Wells, Paul. 2002. Animation: Genre and Authorship. London and New York: Wallflower Press. 